\title{
COMMENT ON FAILURE OF ACCUSED TO TESTIFY
}

The privilege against self-crimination on the part of accused in a criminal case is sanctioned by the Constitution of the United States $^{1}$ and by the constitutions of nearly all of the states. ${ }^{2}$ Although it by no means necessarily follows that the privilege against self-crimination should prohibit the drawing of an inference against one on trial for a crime who avails himself of his privilege, federal legislation ${ }^{3}$ and legislation in all except four of the states prohibits such an inference. ${ }^{4}$ In view of this very

\footnotetext{
${ }^{1}$ Amend. V: "No person . . . . shall be compelled in any criminal case to be a witness against himself."

${ }^{2}$ The accused is protected against self-crimination in all but two of the States. For the phrasing of the various constitutional provisions, see Wigmore, Evidence, Vol. IV, sec. 2252.

In Iowa, the privilege is granted only by statute (1897) Iowa Ann. Code, sec. 5484: "Defendants in all criminal proceedings shall be competent witnesses in their own behalf, but cannot be called as witnesses by the State"; and the same is true in New Jersey. 2 N. J. Comp. St. (19I0) Evidence, sec. 10: "A witness shall not be excused from answering any questions relevant and material to the issue; provided, the answers will not expose him to a criminal prosecution or penalty, or to a forfeiture of his estate."

(I9r3) I U. S. Comp. St., sec. 1465: "In the trial of all indictments . . . . the person so charged shall at his own request but not otherwise, be competent as a witness. And his failure to make such request shall not create any presumption against him."

This statute has been construed as excluding from the jury all comment upon the failure of accused to testify. Wilson $v$. United States (1893) 149 U. S. 60.

"For the phrasing of the various statutory enactments prohibiting an inference or comment, see Wigmore, Evidence, Vol. I, sec. 488, and Vol. IV, sec. 2252.

The four states in which legislation does not prevent the inference are Georgia, New Jersey, Ohio and South Carolina.

In Georgia, the failure of the accused to make a "statement," is not the ground for an inference or comment. Minor $v$. State (1904) I20 Ga. 490 ; Bird v. State (1874) 50 Ga. 585, 58 .

In New Jersey, an inference may be drawn against accused and comment is permitted. State v. Callahan (Ig09) 77 N. J. L. 685, where the court sustained the following charge: "When the accused is upon trial
} 
general condemnation of the practice of drawing an inference against one who takes advantage of his privilege, it may be of interest to those concerned in the administration of the criminal law to consider how the radical change in Ohio, which permits comment, is operating in practice, with a view to determining whether such a change is a wise one.

Among the constitutional amendments submitted to the voters of Ohio, on September 3rd, I9I2, was one which proposed amending Article I, section Io of the Ohio constitution to read in part as follows: "No person shall be compelled, in any criminal case, to be a witness against himself; but his failure to testify may be considered by the court and jury and may be made the subject of comment by counsel." There were 291,7I7 votes cast in favor of the adoption of this amendment and 227,547 against such adoption, and it, therefore, became effective as part of the constitution of Ohio on January Ist, I9I3. Prior to the passage of this amendment, legislation in Ohio had prohibited any comment upon the fact that accused had failed to testify in his own behalf. ${ }^{5}$

A short time ago, the writer submitted to the prosecutors of all of the counties of Ohio a questionnaire asking those elective officials, who are charged with the prosecution of those indicted for crime, to give the benefit of their experience under the recent amendment. Each prosecutor was asked the following questions: "I. How many criminal trials were conducted in your county during the year ending September Ist, 1916? 2. In how many of these trials did accused take the stand in his own behalf? 3. Do you believe that the change which permits the prosecutor to comment on the failure of the accused to testify is a

and the evidence tends to establish facts which, if true, would be conclusive of his guilt of the charge against him, and he can disprove them by his own oath as a witness, if the facts be not true, then his silence would justify a strong inference that he could not deny the charge." State v. Twining (1906) 73 N. J. L. 683; State v. Baniusik (I906) 64 Atl. (N. J.) 994; State v. Wines (1900) 65 N. J. L. 31 ; Parker v. State (I898) 6r N. J. L. 308 .

The Ohio General Code of r9ro, sec. 1366r, provides that: "The neglect or refusal of such person (the accused) to testify shall not create a presumption against him, nor shall reference be made to, nor comment made upon such neglect or refusal," but this provision of the Code was rendered inoperative by a constitutional amendment adopted in ror2.

${ }^{8}$ Ohio Gen. Code of 1910 , sec. 1366r, quoted in note 4 , supra. 
wise one? 4. Would you favor a provision requiring accused to testify against himself even when called by the state?" Answers were received from fifty-two counties, including all of the counties which have cities of any considerable size. These prosecutors reported that they had conducted 1,658 criminal trials during the year. In $\mathrm{r}, 507$ of these cases, the accused took the stand and testified in his own defense. Without exception, each of the fifty-two prosecutors stated that he favored the provision of the Ohio constitution which permitted an inference and comment and many were very emphatic in stating their approval. Fifteen prosecutors were in favor of requiring the accused to testify against himself as a witness for the state, while thirtyseven were opposed to such a requirement. The reports from all these counties showed that in ninety and four-fifths per cent of all cases which actually came to trial the accused took the stand in his own behalf. The four most densely populated counties, in each of which more than one hundred criminal trials were conducted, reported a total of 744 cases, in 725 or ninetyseven and two-fifths per cent of which the defendant elected to testify. In the eleven counties having fifty or more criminal trials each, there were conducted I,I29 cases, and in $\mathrm{I}, 082$, or ninety-five and four-fifths per cent, the accused took the stand. The prosecutor of Cuyahoga County, in which is located Cleveland and which is therefore the most densely populated in Ohio, reported that his office had conducted 375 cases during the year; that all except three defendants took the stand; and that the three who did not avail themselves of the opportunity of testifying were convicted, and all three of these defendants subsequently admitted their guilt.

From the replies submitted it seems evident that, when comment is permitted upon the failure of accused to testify, the defendant usually takes the stand in his own behalf. Should he fail to do so, the prosecutor is in a position to urge the jury to make an inference against the accused in a way which is extremely detrimental to his chances of securing an acquittal. While there are no statistics available which indicate just how large a proportion of defendants took the stand before comment was permitted, it is reasonably certain that the fact of an inference being available for the prosecution has a somewhat decided tendency to cause the accused to take the stand.

Before the practice of drawing an inference can be favored, however, it must be decided whether it is justifiable to bring this 
pressure to bear upon the accused. The few courts that have favored the drawing of an inference from a defendant's exercise of his privilege have sometimes urged that an inference is certain to be made by the jury and that it is useless to seek to avoid it. ${ }^{8}$ The replies of the prosecutors above referred to, show their appreciation of the fact that there is a very practical difference between the bare inference which a jury may make, and the inference driven home as an admission of guilt by skillful counsel. It is sometimes further suggested that the privilege of accused against self-crimination is not violated, since he is not forced to make any reply whatever. ${ }^{7}$ However, since every prosecutor bases his comment upon the hypothesis that any answer which accused could have made, would have been criminating, it is evident that accused really had no option and that he is thus indirectly deprived of his privilege.

To meet fairly the problem of determining the wisdom of permitting an inference from a claim of privilege by accused, it seems that one must admit that the policy supporting a privilege against self-crimination and the policy against permitting an inference from the claim of such privilege differ only in degree. However, so many differences in the application of pripciples which all lawyers recognize, are the results only of differences in degree that this admission does not answer the question as to whether an inference should be permitted.

The fact that prosecutors unanimously favor the permission of comment is not at all surprising, since these men are ordinarily seeking convictions and naturally have little sympathy with obstacles in the way of obtaining the necessary evidence. In

\footnotetext{
-Appleton, C. J., in State v. Cleaves (I87I) $59 \mathrm{Me}$ 298, 30r: "The silence of accused-the omission to explain or contradict, when the evidence tends to establish guilt, is a fact-the probative effect of which may vary according to the varying conditions of the different trials in which it may occur-which the jury may perceive, and which perceiving they can no more disregard than one can the light of the sun, when shining with full blaze on the open eye."

"Appleton, C. J., in State v. Cleaves (187I) 59 Me. 398, 30r: "If innocent, he (the accused) will regard the privilege of testifying as a boon justly conceded. If guilty, it is optional with the accused to testify or not, and he cannot complain of the election he may make. If he does not avail himself of the privilege of contradiction or explanation, it is his own fault, if by his own misconduct or crime he has placed himself in such a situation that he prefers any inference which may be drawn from his refusal to testify, to those which might be drawn from his testimony, if truly delivered."
} 
view of this unanimity in the matter of comment, it is interesting to note that, of these men seeking convictions in criminal cases, thirty-seven out of fifty-two were opposed to a change which would remove the privilege against self-crimination and require accused to testify when called by the state. Various reasons were given by the prosecutors for their opposition to the entire abolition of the privilege against self-crimination but those most commonly given were: "Would lead to perjury," "Would lead to abuse," "Would not be in keeping with the presumption of innocence," "Would be unfair to the accused," "Is unnecessary, since accused is now indirectly forced to take the stand," "Because State should make out a case without requiring accused to testify." Many years ago Bentham ${ }^{8}$ justly criticised some of the reasons above given as introducing into legal procedure the "game" theory, the idea that accused should be given at least a sporting chance for an escape by an acquittal.

There are many thoughtful persons who believe that accused should no longer be granted a privilege against self-crimination.' It is pointed out that the privilege does not protect crimes of the lower order so much as it renders impossible the securing of evidence necessary to convict those guilty of such crimes as bribery, rebating, violation of laws against illegal combinations and similar offenses. Those who support the privilege, therefore, should do so upon something better than mere sentimental grounds.

In an article, a few years ago, ${ }^{10}$ the writer reached a conclusion favorable to the retention for the present of the privilege against compulsory self-disclosure in a criminal case. The guilty deserve no immunity and the conclusion favoring the privilege was based solely on practical considerations in behalf of those accused of crime but in fact innocent. A prosecutor who

\footnotetext{
${ }^{8}$ See Bentham, Works, Vol. VII, p. $45 \mathrm{r}$.

- The Committee on Trial Procedure of the Wisconsin Branch, American Institute of Criminal Law and Criminology, in 19I0, recommended that there be stricken from the constitution the provision that no person should be compelled in any criminal case to be a witness against himself. A resolution embodying this recommendation passed the Senate by the required two-thirds but failed in the Assembly to receive the necessary two-thirds. See (rgiz) 2 Jour. Crm. Law and Crnminology, 870.

See, also, article attacking the privilege by Professor Henry T. Terry, Constitutional Provisions against Forcing Self-Incrimination (I906) I5 YaLE LaW JouRnal, 127.

${ }^{10}$ (r9i3) 3 Jour. CrIm. Law and Criminology, 770.
} 
knows that he cannot interrogate the accused will only subject one under suspicion to a criminal trial when he has somewhat satisfactory independent evidence in proof of the guilt of accused. Where self-crimination is required, the prosecutor is tempted to rely more and more upon his ability to obtain a conviction by reason of defendant's own testimony. The conclusion of Professor Wigmore,"11 "that any system of administration which permits the prosecution to trust habitually to compulsory self-disclosure as a source of proof must itself suffer morally thereby," has found considerable justification in experience. The questioning of the accused in a criminal trial in France certainly does not seem to lead to a more dignified trial than in a similar trial in America. Probably the future will see a farther curtailment of both privileges and disabilities, but, when even prosecutors themselves favor the retention of a privilege, it seems probable that it will be many years before it is abolished in the majority of jurisdictions.

While, as suggested above, the policy against self-crimination differs only in degree from the policy in prohibition of an inference, it is submitted that the difference has such practical results that the decision of those prosecutors who favor the former but oppose the latter may be justified. Under the practice of permitting an inference in Ohio, the prosecution is forced to obtain evidence sufficient to make out a case to go to the jury before it can possibly be in a position to profit by the inference. The prosecution is not tempted to go to trial without sufficient evidence with a view to the establishment of the case from defendant's own testimony. The innocent defendant is therefore not prejudiced by reason of the fact that the prosecutor has relied upon his expected testimony and has therefore made a careless examination of other sources of proof. Without any testimony from the accused, the state must introduce sufficient evidence to cause the grand jury to return an indictment. Without the testimony of accused the state is then required to introduce sufficient admissible evidence so that a jury may find that all the essential elements of the crime charged have been proved. The prosecutor, therefore, is forced to examine others than the accused, and to make such an examination that the innocent accused has reasonable protection against being made the object of a charge in the absence of independent evidence. It seems

${ }^{11}$ Wigmore, Evidence, Vol. IV, p. 3097. 
that the practical consideration which has rendered it unwise entirely to abolish the privilege against self-crimination, namely, the danger that the prosecution would be satisfied with an incomplete examination of other sources, does not weigh heavily when the privilege against self-crimination is retained, and comment is permitted when accused takes advantage of his privilege. Although the accused practically may be forced to testify after the state has introduced evidence, which seems to point toward his guilt, he is not in danger of being placed on trial by an officer who expects to browbeat him and thus elicit sufficient damaging testimony to secure a conviction.

As far as the writer has been able to learn, the provision permitting comment upon failure of accused to testify has not led to abuse in Ohio. The prosecutor's preliminary investigation seems no less thorough and the trial no less dignified. The innocent defendant is deprived of no essential protection, and the guilty accused is deprived only of a shelter to which he is in no way entitled. In a decision by the Supreme Court of the United States ${ }^{12}$ in which only Mr. Justice Harlan dissented, it was held that the exemption from compulsory self-crimination is not one of the fundamental rights, immunities and privileges of citizens of the United States and is not an element of due process of law, within the meaning of the Federal Constitution or the Fourteenth Amendment thereto. The change in the Ohio constitution which permits comment, accordingly, is in no way forbidden by the Federal Constitution.

Whether, therefore, the question of permitting an inference is considered from practical or theoretical grounds, there seems to be no valid. reason against the practice now followed in Ohio, which, while preserving the privilege against self-crimination, permits court and jury to consider the failure of accused to testify and also permits counsel to comment on such failure.

\section{WALTER T. DUNMORE.}

LAW SchOOL, Western Reserve UNIVERSTTY.

${ }^{12}$ Twining v. New Jersey (I908) 2II U. S. 78. 